\title{
KELIMPAHAN DAN KEANEKARAGAMAN SPESIES SERANGGA PREDATOR DAN PARASITOID Aphis gossypii DI SUMATERA SELATAN
}

\author{
Riyanto $^{1}$, Siti Herlinda², Chandra Irsan² \& Abu Umayah² \\ ${ }^{1}$ Program Studi Doktor Ilmu Pertanian, Program Pascasarjana, Universitas Sriwijaya, \\ Jl Padang Selasa No. 524, Bukit Besar, Palembang. E-mail: riyanto1970@yahoo.com \\ ${ }^{2}$ Jurusan Hama dan Penyakit Tumbuhan, Fakultas Pertanian, Universitas Sriwijaya, \\ Jl Raya Palembang-Prabumulih Km 32, Ogan Ilir, Inderalaya 30662. E-mail: sherlinda_hpt_fp@unsri.ac.id
}

\begin{abstract}
The abundance and species diversity of predatory insects and parasitoid of Aphis gossypii in South Sumatra. This study was aimed to analysis abundance and species diversity of predatory insects and parasitoid of Aphis gossypii from lowland and highland areas of South Sumatra. Survey of was conducted in 11 vegetable centers of South Sumatra. The results showed that 20 species of predatory insects and 3 species of parasitoids were found from the survey. The predatory insects consisted of 15 species of coccinellid beetles, two species of syrphids, and one species of chamaemyiid, mantid and staphylinid. Parasitoid found were 2 species of Aphidiidae (Diaretiella rapae and Aphidius sp.) and a species of Aphelinidae (Aphelinus sp.). The highest abundance of the predator was found in Soak (42.61 larvae and adults) and the highest abundance of the parasitoid was found in Talang Buruk (25.99 adults). The highest species diversity of the predator and the parasitoid were found in Soak ( 15 species and $H^{\prime}=0.94$ ) and in Talang Buruk (2 species and $\left.H^{\prime}=0.27\right)$, respectively. Abundance and species diversity of the predators and parasitoids were higher in the dry season than those in rainy season. Thus, the abundance and species diversity of the predators and parasiotids were higher in the lowland than highland areas in South Sumatra, while the seasons affected the abundance and species diversity of the predators and parasitoids.
\end{abstract}

Key words: Aphis gossypii, abundance, parasitoids, predatory insects, species diversity

\section{ABSTRAK}

Kelimpahan dan keanekaragaman spesies serangga predator dan parasitoid Aphis gossypii di Sumatera Selatan. Penelitian ini bertujuan untuk analisis kelimpahan dan keanekaragaman jenis serangga predator dan parasitoid Aphis gossypii dari dataran rendah dan dataran tinggi Sumatera Selatan. Survei dilakukan di 11 lokasi sentra sayur Sumatera Selatan. Hasil penelitian ditemukan 20 jenis serangga predator dan 3 jenis parasitoid. Serangga predator terdiri dari 15 jenis kumbang Coccinellid, 2 jenis larva lalat Syrphid, dan masing-masing 1 jenis Chamaemyiid, Mantid, dan Staphylinid. Parasitoid ditemukan 2 jenis Aphidiid (Diaretiella rapae dan Aphidius sp.) dan 1 jenis Aphelinid (Aphelinus sp.). Kelimpahan serangga predator tertinggi ditemukan di Soak (42,61 larva dan imago) dan kelimpahan parasitoid tertinggi ditemukan di Talang Buruk (25,99 imago). Keanekaragaman jenis serangga predator tertinggi ditemukan di Soak ( 15 spesies dan $\left.H^{`}=0,94\right)$. Keanekaragaman jenis parasitoid tertinggi ditemukan di Talang Buruk ( 2 spesies dan $\mathrm{H}^{\prime}=0,27$ ). Kelimpahan dan keanegaraman spesies serangga predator dan parasitoid lebih tinggi pada musim kemarau dibandingkan musim hujan. Jadi, kelimpahan dan keanekaragaman spesies lebih tinggi di dataran rendah dibandingkan dataran tinggi di Sumatera Selatan, sedangkan musim juga mempengaruhi kelimpahan dan keanekaragaman spesies predator dan parastoid tersebut.

Kata kunci: Aphis gossypii, keanekaragaman, kelimpahan, parasitoid, serangga predator

\section{PENDAHULUAN}

Aphis gossypii (Glover) (Hemiptera: Aphididae) merupakan hama penting tanaman pertanian. Kutu ini juga merupakan vektor berbagai penyakit virus penting tumbuhan. A. gossypii dapat dapat menyerang tanaman pangan dan hortikultura (De-Almeida, 2001). Serangan A. gossypii pada tanaman pangan di California menyebabkan kerugian mencapai \$ 38 juta per tahun
(Godfrey et al., 2000). Kutudaun ini juga telah menyebabkan peledakan penyakit virus pada buahbuahan di Asia tropis (Miyazaki, 2001). Tanaman yang terserang A. gossypii menunjukkan gejala kerdil, daun keriting dan layu, sehingga menurunkan kualitas dan kuntitas produk pertanian (Herlinda, 2010).

A. gossypii ini biasanya dikendalikan menggunakan insektisida sintetik termasuk di Sumatera Selatan. Penggunaan insektisida sintetik yang tidak tepat 
dapat menyebabkan A. gossypii menjadi resisten, mengurangi musuh alami dan polinator (Godfrey et al., 2000; Nauen \& Elbert, 2003). Fernandes et al., (2010) menyatakan akibat aplikasi insektisida menyebabkan resurgensi hama di lapangan dan musuh alami berkurang atau hilang. A. gossypii merupakan kutudaun dominan yang menyerang tanaman sayuran terutama tanaman cabai di agroekosistem Sumatera Selatan (Herlinda, 2010). Untuk itu, perlu dicari alternatif pengendalian yang relatif aman baik bagi produk maupun lingkungan. Pengendalian hayati dengan memanfaatkan musuh alami merupakan salah satu alternatif yang dapat mengatasi permasalahan tersebut.

Banyak jenis musuh alami dilaporkan efektif mengendalikan A. gossypii. Bugg et al. (2008) melaporkan bahwa serangga predator yang memangsa A. gossypii adalah Geocoris sp., Nabis sp., Bembidion sp., Hemerobius pacificus, Hemerobius ovalis, Micromus sp., Chrysopa comanche, C. carnea, C. rufilabris dan Orius tristicolor. Godprey \& McGuire (2004) dan Ma et al. (2006) melaporkan spesies parasitoid yang memarasit A. gossypii adalah Aphelinus sp., Lysiphlebus sp., Aphidius sp., Diaeretiella sp. dan Aphidius gifuensis Ashmead.

Penggunaan musuh alami terbukti efektif untuk mengendalikan kutudaun. Kumbang coccinellid merupakan predator yang efektif memangsa kutudaun di agroekosistem Sri Langka Tengah (Mayadunnage et al., 2007). Aphidius colemani merupakan parasitoid sangat efektif mengendalikan A. gossypii pada pertanaman mentimun di Brazil, karena dapat memarasit A. gossypii 21,2-93\% (Sampaio et al., 2008). Dari latar belakang di atas akibat salah kelola hama termasuk
A. gossypii menyebabkan terjadi perubahan kelimpahan dan keanekaragaman musuh alami $A$. gossypii. Oleh karena itu, informasi kelimpahan dan keanekaragaman spesies serangga predator dan parasitoid A. gossypii sangat penting untuk diungkapkan. Tujuan penelitian ini adalah untuk menganalisis kelimpahan dan keanekaragaman spesies serangga predator dan parasitoid A. gossypii di agroekosistem dataran rendah dan dataran tinggi Sumatera Selatan.

\section{METODE PENELITIAN}

Penelitian ini dilaksanakan di sentra produksi sayuran dataran rendah dan dataran tinggi Sumatera Selatan dengan ketinggian tempat $10-1430 \mathrm{~m}$ di atas permukaan laut (m dpl) (Tabel 1). Produksi sayur di dataran rendah didominasi sayur dari famili Solanaceae, sedangkan di dataran tinggi didominasi sayur dari famili Brassicaceae. Aplikasi insektisida berdasarkan survei di dataran rendah \pm 4 hari sekali, sedangkan di dataran tinggi volume penyemprotan relatif lebih tinggi, yaitu \pm 2 hari sekali. Pada musim kemarau rerata suhu $35,56^{\circ} \mathrm{C}$, kelembaban 56,27 dan curah hujan 13,33 mm per hari, sedangkan pada musim hujan rerata suhu $32,56^{\circ} \mathrm{C}$, kelembaban 66,27 dan curah hujan 17,33 mm per hari. Identifikasi serangga predator dan parasitoid A. gossypii dilakukan di laboratorium Entomologi Jurusan HPT, Fakultas Pertanian, Universitas Sriwijaya.

Survei serangga predator dan parasitoid dilakukan secara visual dan diamati langsung pada tumbuhan inang yang dikoloni dan diserang oleh A. gossypii. Survei dan eksplorasi tersebut dilakukan dengan menggunakan transek garis sejauh $3 \mathrm{~km}$ pada masing-masing sentra

Tabel 1. Lokasi survei dan ketinggiannya

\begin{tabular}{clc}
\hline Tipe Geografi & \multicolumn{1}{c}{ Lokasi sentra sayuran } & Ketinggian lokasi (m dpl) \\
\hline Dataran rendah & Kenten (Kab. Banyuasin) & 11 \\
& Soak (Kota Palembang) & 10 \\
& Talang Buruk (Kota Palembang) & 11 \\
& Tanjungraja (Kab. Ogan Ilir) & 11 \\
& Indralaya (Kab. Ogan Ilir) & 14 \\
& Gelumbang (Kab. Muaraenim) & 20 \\
Dataran tinggi & Kerinjing (Kota Pagar Alam) & 1430 \\
& Muarasiban (Kota Pagar Alam) & 1080 \\
& Pagardin (Kota Pagar Alam) & 1030 \\
& Bedeng Kresek (Kota Pagar Alam) & 1300 \\
& Jarai (Kab. Lahat) & 900 \\
\hline
\end{tabular}


produksi sayuran. Jika panjang satu lokasi contoh tidak mencapai jarak tersebut, maka diadakan pembelokan ke arah semula dengan jarak $1 \mathrm{~m}$ dari garis yang telah dilewati (modifikasi Khan, 2006 atau Khan et al., 2006). Pengamatan terhadap parasitoid dan serangga predator dilakukan pada transek garis dengan luas minimal tumbuhan inang A. gossypii $100 \mathrm{~m}^{2}$ atau luas tiap titik pengamatan di transek minimal $100 \mathrm{~m}^{2}$. Jumlah sampel pada tiap lokasi atau transek adalah seluruh serangga predator dan parasitoid yang berhasil dikoleksi. Survei dan eksplorasi dilakukan sebanyak enam kali per lokasi, yaitu tiga kali pada musim hujan dan tiga kali pada musim kemarau dengan selang antara satu pengamatan dengan pengamatan berikutnya satu bulan.

Koleksi parasitoid. Koleksi parasitoid dilakukan koleksi mumi A. gossypii terdahulu di tanaman sayuran dan tumbuhan liar. Mumi A. gossypii yang ditemukan di setiap lokasi pada tumbuhan inang yang berbeda dimasukkan ke dalam kapsul gelatin No. 00 (Lilly Co.). Lalu kapsul-kapsul tersebut dimasukkan ke dalam cawan Petri. Jumlah imago parasitoid yang muncul dan imago A. gossypii yang ada dicatat untuk menentukan tingkat parasitisasi. Pada saat melalukan pengambilan contoh dilakukan pendataan tentang spesies-spesies tumbuhan inang A. gossypii di setiap lokasi pengamatan. Imago parasitoid yang muncul dari kapsul gelatin dimasukkan dalam botol vial yang berisi alkohol 70\%. Parasitoid $A$. gossypii yang ditemukan selanjutnya diidentifikasi.

Koleksi serangga predator. Koleksi serangga predator dilakukan pada koloni A. gossypii di tanaman sayur dan tumbuhan liar. Semua spesies serangga predator yang ditemukan memangsa $A$. gossypii dikoleksi. Koleksi serangga predator dilakukan dengan pengambilan contoh setiap spesies dengan menggunakan jaring serangga atau ditangkap dengan tangan. Serangga predator yang tertangkap langsung dimasukkan dalam botol vial yang berisi alkohol $70 \%$.

Identifikasi parasitoid. Identifikasi dilakukan dengan mengamati spesimen parasitoid awetan. Identifikasi spesimen menggunakan ciri-ciri morfologi sayap dan antena. Berdasarkan ciri-ciri morfologi itu selanjutnya diidentifikasi menggunakan kunci identifikasi spesies parasitoid A. gossypii. Kunci identifikasi itu antara lain ditulis oleh Stary (1988a), Stary (1988b) dan Stary et al. (2008).

Identifikasi serangga predator. Identifikasi dilakukan dengan mengamati spesimen serangga awetan.
Identifikasi spesimen menggunakan ciri-ciri morfologi sayap, antena dan toraks. Selanjutnya berdasarkan ciriciri morfologi diidentifikasi menggunakan kunci identifikasi yang memuat spesies serangga predator A. gossypii, yaitu Frechette at al. (2009); Joshi \& Sharma (2008); Mayadunnage et al. (2007) dan Amir (2002).

Analisis data. Data komposisi dan kelimpahan spesies serangga predator dan parasitoid digunakan untuk menganalisis indeks keanekaragaman spesies Shanon (H'), indeks dominasi spesies Berger-Perker (d) dan indeks kemerataan spesies (e) (Lugwig \& Reynolds, 1988). Uji-t menggunakan program computer SPSS versi 11.5 digunakan untuk membandingkan data musim hujan dan kemarau.

\section{HASIL DAN PEMBAHASAN}

\section{Kelimpahan dan Keanekaragaman Spesies} Serangga Predator Aphis gossypii. Hasil survei menunjukkan di dataran rendah dan tinggi Sumatera Selatan dapat ditemukan 20 spesies serangga predator yang dapat menyerang A. gossypii. Serangga predator terdiri dari 15 spesies Coccinellidae, 2 spesies Syrphidae dan masing 1 spesies dari Chamaemyiidae, Mantidae dan Staphylinidae (Tabel 2). Brewer \& Elliot (2004) juga melaporkan bahwa serangga predator utama kutudaun dari famili Coccinellidae, Syrphidae, Chamaemyiidae, Staphylinidae dan Chrysopidae. Sebelumnya Irsan (2003) juga menemukan 5 spesies serangga predator yang memangsa $A$. gossypii yang tergolong dalam tiga famili, yaitu Coccinellidae, Syrphidae dan Hemerobiidae. Dilihat dari jumlah spesiesnya famili Coccineliidae merupakan pemangsa utama A. gossypii di agroekosistem sayur Sumatera Selatan. Joshi \& Sharma (2008) juga menyatakan bahwa kumbang coccinellid merupakan pemangsa utama kutudaun di agroekosistem Haridwar India.

Kelimpahan serangga predator tertinggi di dataran rendah ditemukan di Soak, yaitu 42,61 ekor per $100 \mathrm{~m}^{2}$ pada musim kemarau (Tabel 3), sedangkan di dataran tinggi ditemukan di Muarasiban, yaitu 19,32 ekor per $100 \mathrm{~m}^{2}$ pada musim hujan (Tabel 4). Kelimpahan serangga predator di agroekosistem sayur Sumatera Selatan berkaitan erat dengan vegetasi tumbuhan sekitar lahan. Kenyataan pada saat survei di sekitar sentra sayur Soak dan Muarasiban lebih banyak vegetasi tumbuhan berupa semak belukar dan rawa yang banyak tumbuhan. Outward et al. (2008) menyatakan vegetasi tumbuhan di sekitar lahan pertanian kapas dapat 
Tabel 2. Spesies serangga predator Aphis gossypii di Sumatera Selatan.

\begin{tabular}{|c|c|}
\hline Spesies predator & Lokasi sentra sayuran \\
\hline \multicolumn{2}{|c|}{ Dataran Rendah } \\
\hline \multicolumn{2}{|l|}{ Coccinellidae } \\
\hline Cheilomenes sexmaculata (Fabricius) & $\begin{array}{l}\text { Kenten, Soak, Talang Buruk, Tanjungraja, } \\
\text { Indralaya dan Gelumbang. }\end{array}$ \\
\hline Harmonia conformis (Boisduval) & Soak \\
\hline Coccinella repanda (Thunberg) & Soak, Indralaya dan Gelumbang \\
\hline Coelophora pupillata (Swartz)* & Kenten dan Soak \\
\hline Coelophora 9 maculata (Thunberg) & Kenten, Soak, Tanjungraja dan Indralaya \\
\hline Verania lineate (Thunberg)* & Gelumbang \\
\hline Coelophora inaequalis (Fabricius)* & Soak \\
\hline Coelophora reninplagiata (Mulsant)* & Soak dan Tajungraja \\
\hline Verania discolor (Fabricius)* & Soak dan Talang Buruk \\
\hline Chilocorus politus (Mulsant)* & Kenten dan Soak. \\
\hline Chilocorus melanophthalmus (Mulsant) & Kenten, Soak dan Indralaya. \\
\hline Chilocorus ruber (Weise) & Soak \\
\hline Cryptolaemus sp.* & Soak, Tanjungraja, Indralaya dan Gelumbang. \\
\hline Syrphidae & \\
\hline Sphaerophosis sp. & Kenten, Soak dan Talang Buruk \\
\hline Ischiodon scutellaris & Kenten dan Soak \\
\hline Chamaemyiidae & \\
\hline Larva lalat Chamaemyiidae* & Talang Buruk dan Gelumbang \\
\hline \multicolumn{2}{|l|}{ Mantidae } \\
\hline Mantis sp. & Kenten, Soak dan Talang Buruk \\
\hline \multicolumn{2}{|c|}{ Dataran Tinggi } \\
\hline \multicolumn{2}{|l|}{ Coccinellidae } \\
\hline Cheilomenes sexmaculata (Fabricius) & Pagardin, Bedeng Kresek dan Jarai \\
\hline Harmonia conformis & Kerinjing \\
\hline Coccinella repanda (Thunberg) & $\begin{array}{l}\text { Muarasiban, Pagardin, Bedeng Kresek dan } \\
\text { Jarai. }\end{array}$ \\
\hline Coccinella arcuata (Fabricius)** & Muarasiban \\
\hline Coelophora 9 maculata (Thunberg) & Kerinjing, Pagardin, dan Bedeng Kresek. \\
\hline Chilocorus melanophthalmus (Mulsant) & Kerinjing, Muarasiban, Pagardin dan Jarai. \\
\hline Curinus coeruleus (Mulsant)** & Muarasiban \\
\hline Chilocorus ruber (Weise) & Kerinjing, Muarasiban dan Bedeng kresek \\
\hline Syrphidae & \\
\hline Sphaerophosis sp. & Muarasiban dan Bedeng Kresek \\
\hline Ischiodon scutellaris & Muarasiban, Pagardin dan Bedeng Kresek. \\
\hline $\begin{array}{l}\text { Staphylinidae } \\
\text { Philonthus sp. }{ }^{* *}\end{array}$ & Kerinjing \\
\hline Mantidae & \\
\hline Mantis sp. & Kerinjing dan Bedeng Kresek \\
\hline
\end{tabular}

Keterangan: $*$ = hanya ditemukan di dataran rendah. $* *=$ hanya ditemukan di dataran tinggi 
Tabel 3. Kelimpahan dan keanekaragaman spesies serangga predator A. gossypii di dataran rendah Sumatera Selatan pada musim kemarau dan hujan

\begin{tabular}{|c|c|c|}
\hline Karakteristik komunitas & Kemarau & Hujan \\
\hline \multicolumn{3}{|l|}{ Kenten } \\
\hline Kelimpahan/jumlah spesimen (ekor) & 6,31 & 11,99 \\
\hline Jumlah spesies & 6,00 & 6,00 \\
\hline Indeks keanekaragam spesies (H’) & 0,62 & 0,53 \\
\hline Indeks dominasi spesies & 0,36 & 0,50 \\
\hline Indeks kemerataan spesies & 0,34 & 0,29 \\
\hline \multicolumn{3}{|l|}{ Soak } \\
\hline Kelimpahan/jumlah spesimen (ekor) & 42,61 & 5,31 \\
\hline Jumlah spesies & 15,00 & 7,00 \\
\hline Indeks keanekaragam spesies (H’) & 0,94 & 0,72 \\
\hline Indeks dominasi spesies & 0,32 & 0,37 \\
\hline Indeks kemerataan spesies & 0,35 & 0,37 \\
\hline \multicolumn{3}{|l|}{ Talang Buruk } \\
\hline Kelimpahan/jumlah spesimen (ekor) & 6,32 & 1,99 \\
\hline Jumlah spesies & 3,00 & 3,00 \\
\hline Indeks keanekaragam spesies (H’) & 0,27 & 0,37 \\
\hline Indeks dominasi spesies & 0,57 & 0,66 \\
\hline Indeks kemerataan spesies & 0,24 & 0,34 \\
\hline \multicolumn{3}{|l|}{ Tanjungraja } \\
\hline Kelimpahan/jumlah spesimen (ekor) & 6,32 & 4,66 \\
\hline Jumlah spesies & 4,00 & 3,00 \\
\hline Indeks keanekaragam spesies (H’) & 0,35 & 0,46 \\
\hline Indeks dominasi spesies & 0,73 & 0,42 \\
\hline Indeks kemerataan spesies & 0,25 & 0,41 \\
\hline \multicolumn{3}{|l|}{ Indralaya } \\
\hline Kelimpahan/jumlah spesimen (ekor) & 9,65 & 3,98 \\
\hline Jumlah spesies & 5,00 & 5,00 \\
\hline Indeks keanekaragam spesies (H’) & 0,49 & 0,65 \\
\hline Indeks dominasi spesies & 0,55 & 0,33 \\
\hline Indeks kemerataan spesies & 0,31 & 0,40 \\
\hline \multicolumn{3}{|l|}{ Gelumbang } \\
\hline Kelimpahan/jumlah spesimen (ekor) & 6,32 & 2,32 \\
\hline Jumlah spesies & 5,00 & 4,00 \\
\hline Indeks keanekaragam spesies (H’) & 0,59 & 0,55 \\
\hline Indeks dominasi spesies & 0,47 & 0,43 \\
\hline Indeks kemerataan spesies & 0,36 & 0,39 \\
\hline
\end{tabular}

Keterangan= Luas areal survei $400 \mathrm{~m}^{2}$. 
Tabel 4. Kelimpahan dan keanekaragaman spesies serangga predator A. gossypii di dataran tinggi Sumatera Selatan pada musim kemarau dan hujan

\begin{tabular}{|c|c|c|}
\hline Karakteristik komunitas & Kemarau & Hujan \\
\hline Kerinjing & & \\
\hline $\begin{array}{l}\text { Kelimpahan/jumlah spesimen (ekor) } \\
\text { Jumlah spesies } \\
\text { Indeks keanekaragam spesies (H’) } \\
\text { Indeks dominasi spesies } \\
\text { Indeks kemerataan spesies }\end{array}$ & $\begin{array}{c}2,98 \\
4,00 \\
0,49 \\
0,55 \\
0,35\end{array}$ & $\begin{array}{l}0,99 \\
3,00 \\
0,47 \\
0,33 \\
0,43\end{array}$ \\
\hline $\begin{array}{l}\text { Muarasiban } \\
\text { Kelimpahan/jumlah spesimen (ekor) } \\
\text { Jumlah spesies } \\
\text { Indeks keanekaragam spesies (H’) } \\
\text { Indeks dominasi spesies } \\
\text { Indeks kemerataan spesies }\end{array}$ & $\begin{array}{c}8,98 \\
8,00 \\
0,63 \\
0,55 \\
0,30\end{array}$ & $\begin{array}{l}19,32 \\
3,00 \\
0,07 \\
0,96 \\
0,06\end{array}$ \\
\hline $\begin{array}{l}\text { Pagardin } \\
\text { Kelimpahan/jumlah spesimen (ekor) } \\
\text { Jumlah spesies } \\
\text { Indeks keanekaragam spesies (H’) } \\
\text { Indeks dominasi spesies } \\
\text { Indeks kemerataan spesies }\end{array}$ & $\begin{array}{c}2,31 \\
5,00 \\
0,67 \\
0,28 \\
0,41\end{array}$ & $\begin{array}{l}- \\
- \\
- \\
-\end{array}$ \\
\hline $\begin{array}{l}\text { Bedeng Kresek } \\
\text { Kelimpahan/jumlah spesimen (ekor) } \\
\text { Jumlah spesies } \\
\text { Indeks keanekaragam spesies (H’) } \\
\text { Indeks dominasi spesies } \\
\text { Indeks kemerataan spesies }\end{array}$ & $\begin{array}{l}4,31 \\
5,00 \\
0,61 \\
0,38 \\
0,38\end{array}$ & $\begin{array}{l}0,66 \\
2,00 \\
0,30 \\
0,50 \\
0,43\end{array}$ \\
\hline $\begin{array}{l}\text { Jarai } \\
\text { Kelimpahan/jumlah spesimen (ekor) } \\
\text { Jumlah spesies } \\
\text { Indeks keanekaragam spesies (H’) } \\
\text { Indeks dominasi spesies } \\
\text { Indeks kemerataan spesies }\end{array}$ & $\begin{array}{l}0,66 \\
2,00 \\
0,30 \\
0,50 \\
0,43\end{array}$ & $\begin{array}{l}4,98 \\
3,00 \\
0,48 \\
0,60 \\
0,43 \\
\end{array}$ \\
\hline
\end{tabular}

Keterangan= Luas areal survei $400 \mathrm{~m}^{2}$.

meningkatkan kelimpahan arthropoda predator. Hal itu menunjukkan predator A. gossypii di Soak dan Muarasiban berasal dari vegetasi sekitar lahan.

Kelimpahan serangga predator pada musim kemarau lebih tinggi dibandingkan musim hujan di Soak, Talang Buruk, Tanjungraja, Indralaya, Gelumbang, Kerinjing, Pagardin, Bedeng Kresek, kecuali di Kenten, Muarasiban dan Jarai lebih tinggi musim hujan atau dengan kata lain secara umum kelimpahan serangga predator di agroekosistem sayur Sumatera Selatan lebih tinggi di musim kemarau (Tabel 3 dan Tabel 4). Kelimpahan serangga predator di berbagai lokasi sentra sayur berkaitan erat dengan kelimpahan A. gossypii di lapangan. Kenyataannya pada musim kemarau kelimpahan populasi A. gossypii lebih tinggi dibandingkan dengan musim hujan. Idris et al. (2001) menyatakan kelimpahan predator kumbang coccinellid yang memangsa $A$. gossypii di agroekosistem berkaitan erat dengan kelimpahan populasi A. gossypii di lapangan. Kekayaan flora di lahan atau di sekitar lahan sayur pada musim kemarau turut mempengaruhi kelimpahan serangga predator. Pada umumnya di musim kemarau vegetasi tanaman sayur lebih beragam dibandingkan musim hujan. Kuznetsov \& Zakharov (2001) juga 
melaporkan bahwa salah satu faktor yang menentukan penyebaran kumbang coccinellid adalah kekayaan flora.

Keanekaragaman spesies serangga predator tertinggi ditemukan di Soak dengan jumlah 15 spesies dan $\mathrm{H}^{\prime}=0,94$ (Tabel 3), sedangkan di dataran tinggi hanya ditemukan 8 spesies dan H'=0,63 di Muarasiban (Tabel 4). Faktor yang mempengaruhi keanekaragaman spesies predator di Soak dan Muarasiban adalah keterhubungan kedua lokasi dengan lanskap vegetasi sekitarnya. Habitat sekitar pertanaman sayur di Soak dan Muarasiban yang terdiri atas semak belukar, hutan sekunder dan rawa yang berumput turut mempengaruhi keberadaan serangga predator. Bugg et al. (2008) menyatakan artropoda yang menguntungkan dapat menghuni agroekosistem sayur berasal dari hutan (wildlands), tanaman pagar, tumbuhan liar dan lahan sayuran. Artinya ekosistem di Soak dan Muarasiban yang kompleks menyediakan beragam tipe habitat sehingga lebih banyak spesies predator dapat berkoeksistensi di dalamnya.

Keanekaragaman spesies serangga predator pada musim kemarau lebih tinggi dibandingkan musim hujan di Kenten, Soak, Gelumbang, Kerinjing, Muarasiban, Pagardin dan bedeng Kresek, sebaliknya di Talang Buruk, Tanjungraja, Indralaya dan Jarai lebih tinggi di msuim hujan atau secara umum keanekaragam spesies predator A. gossypii di agroekosistem sayur pada musim kemarau lebih tinggi dibandingkan musim hujan (Tabel 3 dan Tabel 4). Keanekaragaman spesies predator berkaitan serat dengan kelimpahan populasi A. gossypii dan tumbuhan inang pada musim kemarau. Kenyataan di lapangan pada musim kemarau populasi A. gossypii dan tumbuhan inang lebih banyak dan beragam. Hal ini menyebabkan serangga predator yang dikoleksi pada musim kemarau lebih banyak spesies dan kelimpahannya dibandingkan husim hujan.

\section{Kelimpahan dan Keanekaragaman Spesies} Parasitoid Aphis gossypii. Dari penelitian ini telah ditemukan parasitoid sebanyak 3 spesies, yaitu 2 spesies famili Aphidiidae (Diaretiella rapae dan Aphidius sp.) dan 1 spesies famili Aphelinidae (Aphelinus sp.) (Tabel 5). Hasil penelitian ini mirip dengan yang dilaporkan Irsan (2003) bahwa parasitoid A. gossypii adalah $A$. delicatus Baker, Aphidius sp., Diaeretiella sp., Tryoxis sinensis Mackauer dan Aphelinus sp. Ditambahkan oleh Wei et al. (2005) parasitoid kutudaun adalah A. gifuensis, A. ervi haliday dan Aphelinus mali Haldeman. Kemiripan spesies dan famili parasitoid yang ditemukan Irsan (2003) dan Wei et al. (2005) berkaitan erat dengan kemiripan inangnya, yaitu $A$. gossypii.

Kelimpahan parasitoid tertinggi di dataran rendah ditemukan di Talang Buruk, yaitu 25,99 ekor per $100 \mathrm{~m}^{2}$ pada musim kemarau (Tabel 6), sedangkan di dataran tinggi ditemukan di Kerinjing dan Muarasiban, yaitu 2,33 ekor per $100 \mathrm{~m}^{2}$ pada musim kemarau (Tabel 7). Kelimpahan parasitoid erat kaitannya dengan keberadaan vegetasi sekitar lahan, kelimpahan populasi A. gossypii dan tumbuhan inangnya. Kenyataan di lapangan sentra sayur Talang Buruk memiliki lebih banyak vegetasi tumbuhan berbunga terutama di rawarawa yang menyediakan makan imago, inang alternatif dan tempat berlindung. Hochberg \& Ives (2000) menyatakan bahwa keberadaan vegetasi di sekitar tanaman semusim dapat meningkatkan keberadaan populasi parasitoid, karena tersedia sumber makanan imago, inang alternatif dan untuk kelangsungan hidup parasitoid. Habitat yang alami di sekitar tanaman semusim dapat menunjang populasi musuh alami yang menyebar ke dalam lahan tanaman semusim. Ditambahkan oleh Rakhshani et al. (2008) sebaran Aphidius sp. berkaitan erat dengan distribusi kutudaun dan tumbuhan inang kutudaun. He et al. (2006) ratarata kepadatan populasi $A$. ervi meningkat secara nyata seiring dengan meningkatnya kepadatan inang kutudaunnya. Dengan demikian dapat dikatakan kelimpahan Aphidius sp. dan D. rapae karena tersedianya $A$. gossypii sebagai serangga inang untuk berkembangbiak.

Pada penelitian ini parasitoid A. gossypii tidak ditemukan di Pagardin, Bedeng Kresek dan Tanjungraja (Tabel 6 dan Tabel 7). Salah satu penyebab parasitoid tidak ditemukan di ketiga lokasi ini ialah penggunaan insektisida yang intensif oleh petani. Hasil survei selama penelitian aplikasi insektisida di dataran rendah \pm 4 hari sekali, sedangkan di dataran tinggi volume penyemprotan relatif lebih tinggi, yaitu \pm 2 hari sekali. Wei et al., (2005) menyatakan aplikasi insektisida intensif terhadap kutudaun dapat membunuh banyak musuh alami termasuk parasitoid. Oleh karena itu, aplikasi pestisida harus dibatasi waktu, kuantitas dan intervalnya untuk menciptakan habitat yang cocok bagi musuh alami.

Kelimpahan parasitoid pada musim kemarau lebih tinggi dibandingkan musim hujan di Kenten, Soak, Talang Buruk, Gelumbang, Kerinjing, Muarasiban dan Jarai kecuali di Indralaya lebih tinggi pada musim hujan (Tabel 6 dan 7). Kelimpahan parasitoid erat kaitannya dengan suhu dan populasi A. gossypii di musim kemarau. Parasitoid lebih efektif melakukan aktivitas metabolisme pada suhu yang lebih tinggi. Artinya suhu tinggi dapat 
Tabel 5. Spesies parasitoid Aphis gossypii di Sumatera Selatan

\begin{tabular}{lll}
\hline \multirow{2}{*}{ Spesies parasitoid } & \multicolumn{2}{c}{ Lokasi sentra sayuran } \\
\cline { 2 - 3 } & \multicolumn{1}{c}{ Dataran Rendah } & Dataran Tinggi \\
\hline Aphidiidae & Kenten, Talang Buruk, Indralaya dan Gelumbang & Muarasiban \\
Aphidius sp. & Talang Buruk dan Gelumbang & Kerinjing dan Jarai \\
Diaretiella rapae & & \\
Aphelinidae & Kenten dan Soak & \\
Aphelinus sp. & & \\
\hline
\end{tabular}

Keterangan: $*$ = hanya ditemukan di dataran rendah. ** = hanya ditemukan di dataran tinggi.

Tabel 6. Kelimpahan dan keanekaragaman spesies parasitoid Aphis gossypii di dataran rendah Sumatera Selatan pada musim hujan dan kemarau

\begin{tabular}{|c|c|c|}
\hline Karakteristik komunitas & Kemarau & Hujan \\
\hline \multicolumn{3}{|l|}{ Kenten } \\
\hline Kelimpahan/jumlah spesimen (ekor) & 1,83 & 0 \\
\hline Jumlah spesies & 2,00 & 0 \\
\hline Indeks keanekaragam spesies (H’) & 0,20 & 0 \\
\hline Indeks dominasi spesies & 0,81 & 0 \\
\hline Indeks kemerataan spesies & 0,29 & 0 \\
\hline \multicolumn{3}{|l|}{ Soak } \\
\hline Kelimpahan/jumlah spesimen (ekor) & 0,66 & 0 \\
\hline Jumlah spesies & 1,00 & 0 \\
\hline Indeks keanekaragam spesies (H’) & 0 & 0 \\
\hline Indeks dominasi spesies & 1,00 & 0 \\
\hline Indeks kemerataan spesies & 0 & 0 \\
\hline \multicolumn{3}{|l|}{ Talang Buruk } \\
\hline Kelimpahan/jumlah spesimen (ekor) & 25,99 & 0 \\
\hline Jumlah spesies & 2,00 & 0 \\
\hline Indeks keanekaragam spesies (H’) & 0,27 & 0 \\
\hline Indeks dominasi spesies & 0,66 & 0 \\
\hline Indeks kemerataan spesies & 0,39 & 0 \\
\hline \multicolumn{3}{|l|}{ Tanjungraja } \\
\hline Tidak ditemukan parasitoid A. gossypii & 0 & 0 \\
\hline \multicolumn{3}{|l|}{ Indralaya } \\
\hline Kelimpahan/jumlah spesimen (ekor) & 0 & 0,66 \\
\hline Jumlah spesies & 0 & 1,00 \\
\hline Indeks keanekaragam spesies (H’) & 0 & 0 \\
\hline Indeks dominasi spesies & 0 & 1,00 \\
\hline Indeks kemerataan spesies & 0 & 0 \\
\hline \multicolumn{3}{|l|}{ Gelumbang } \\
\hline Kelimpahan/jumlah spesimen (ekor) & 10,66 & 0 \\
\hline Jumlah spesies & 2,00 & 0 \\
\hline Indeks keanekaragam spesies (H’) & 0,13 & 0 \\
\hline Indeks dominasi spesies & 0,90 & 0 \\
\hline Indeks kemerataan spesies & 0,19 & 0 \\
\hline
\end{tabular}

Keterangan= Luas areal survei $400 \mathrm{~m}^{2}$. 
Tabel 7. Kelimpahan dan keanekaragaman spesies parasitoid Aphis gossypii di dataran tinggi Sumatera Selatan pada musim hujan dan kemarau

\begin{tabular}{lll}
\hline \multicolumn{1}{c}{ Karakteristik komunitas } & Kemarau & Hujan \\
\hline Kerinjing & & 0 \\
Kelimpahan/jumlah spesimen (ekor) & 2,33 & 0 \\
Jumlah spesies & 1,00 & 0 \\
Indeks keanekaragam spesies (H') & 0 & 0 \\
Indeks dominasi spesies & 1,00 & 0 \\
Indeks kemerataan spesies & 0 & \\
Muarasiban & & 0 \\
Kelimpahan/jumlah spesimen (ekor) & 2,33 & 0 \\
Jumlah spesies & 1,00 & 0 \\
Indeks keanekaragam spesies (H') & 0 & 0 \\
Indeks dominasi spesies & 1,00 & 0 \\
Indeks kemerataan spesies & 0 & 0 \\
Pagardin & & \\
Tidak ditemukan parasitoid A. gossypii & 0 & 0 \\
Bedeng Kresek & & \\
Tidak ditemukan parasitoid A. gossypii & 0 & 0 \\
Jarai & & 0 \\
Kelimpahan/jumlah spesimen (ekor) & 0,33 & 0 \\
Jumlah spesies & 1,00 & 0 \\
Indeks keanekaragam spesies (H') & 0 & 0 \\
Indeks dominasi spesies & 1,00 & \\
Indeks kemerataan spesies & 0 & \\
\hline Ketrangan= Luas areal survei 400 m². & & \\
\hline
\end{tabular}

Keterangan= Luas areal survei $400 \mathrm{~m}^{2}$.

mempercepat aktivitas parasitoid termasuk memarasit A. gossypii dan inangnya lebih berlimpah. Dinyatakan oleh Schirmer et al. (2008) bahwa tingkat parasitisasi parasitoid Aphelinus asychis dipengaruhi oleh suhu, intensitas cahaya dan kelembaban nisbih udara. Giovanni et al. (2000) menambahkan bahwa Lysiphlebus testaceipes yang merupakan parasitoid yang memarasit A. gossypii lebih efektif memarasit pada suhu tinggi dibandingkan suhu rendah. Kenyataan hasil pengukuran suhu di agroekosistem sayur pada musim kemarau rerata $35,56^{\circ} \mathrm{C}$ dan sedangkan musim hujan rerata $32,56{ }^{\circ} \mathrm{C}$. Dengan demikian diyakini bahwa tinngginya kelimpahan parasitoid pada musim kemarau terutama di dataran rendah dipengaruhi oleh suhu yang lebih tinggi.

Keanekaragaman spesies parasitoid tertinggi ditemukan dataran rendah (Talang Buruk) dengan jumlah 2 species dan $\mathrm{H}^{\prime}=0,27$ (Tabel 6), sedangkan di dataran tinggi hanya ditemukan 1 spesies masing-masing di Kerinjing, Muarasiban dan Jarai dan $\mathrm{H}^{\prime}=0$. Secara keseluruhan di dataran rendah ditemukan 3 spesies, yaitu Aphidius sp., D. rapae dan Aphelinus sp., sedangkan di dataran tinggi dua sepses, yaitu Aphidius sp. dan $D$. rapae (Tabel 7). Keanekaragaman di dataran rendah lebih lebih tinggi daripada dataran tinggi. Hal ini erat kaitannya dengan beragamnya tipe habitat seperti rawa dan semak belukar atau hutan sekunder yang merupakan sumber invasi parasitoid. Brewer \& Elliot (2004) menyatakan keanekaragam tumbuhan yang berada di sekitar tanaman budidaya dapat mempengaruhi kehadiran parasitoid kutudaun. Dengan demikian dapat dikatakan bahwa vegetasi di sekitar lahan dapat mendukung keanekaragaman parasitoid di Talang Buruk (dataran rendah).

Keanekaragaman spesies parasitoid pada musim kemarau lebih tinggi hanya di tiga sentra sayur dataran rendah, yaitu Kenten, Talang Buruk dan Gelumbang dibandingkan musim hujan di ketiga sentra sayur tersebut 
(Tabel 6 dan Tabel 7). Pada musim kemarau faktor lingkungan lebih mendukung untuk perkembangan berbagai spesies parasitoid. Dinyatakan oleh Herlinda (2005), Cotesia plutellae (Kurdj.) yang merupakan parasitoid Plutella xylostella L. lebih sesuai berkembangbiak pada suhu lebih tinggi. Kenyataannya pada penelitian ini rerata suhu lebih tinggi pada musim kemarau rerata suhu $35,56^{\circ} \mathrm{C}$, sedangkan pada musim hujan rerata suhu $32,56^{\circ} \mathrm{C}$. Dengan demikian dapat dikatakan faktor abiotik seperti suhu pada musim kemarau lebih sesuai untuk berbagai spesies parasitoid berkembangbiak dibandingkan musim hujan. Pada musim hujan keanekaragaman parasitoid di seluruh lokasi survei 0 , karena hanya ditemukan 1 spesies saja, yaitu di Indralaya sehingga hasil perhitungan indeks keanekaragaman adalah $0\left(\mathrm{H}^{\prime}=0\right)$. Fenomena ini dapat terjadi diyakini pada musim hujan lahan sayur terutama di dataran tinggi beralih ke tanaman padi sehingga kondisi lingkungan bagi parasitoid berubah. Hochberg \& Ives (2000) menyatakan bahwa konservasi musuh alami pada tanaman pangan semusim monokultur sulit dilakukan, karena kelangsungan hidup parasitoid sangat singkat. Pada saat panen lahan dibersihkan, sehingga dibutuhkan rekolonisasi pada masa tanaman berikutnya.

\section{SIMPULAN}

Dari hasil penelitian dapat disimpulkan bahwa di dataran rendah dan tinggi Sumatera Selatan dapat ditemukan 20 spesies serangga predator dan 3 spesies parasitoid yang menyerang A. gossypii. Serangga predator terdiri dari 15 speseis Coccinellidae, 2 spesies Syrphidae dan masing 1 spesies dari Chamaemyiidae, Mantidae, dan Staphylinidae. Parasitoid yang ditemukan ialah 2 spesies Aphidiidae (Diaretiella rapae dan Aphidius sp.) dan 1 spesies Aphelinidae (Aphelinus sp.). Kelimpahan serangga predator tertinggi ditemukan di Soak (42,61 larva dan imago) dan parasitoid tertinggi ditemukan di Talang Buruk (25,99 imago). Keanekaragaman spesies serangga predator tertinggi ditemukan di Soak (15 spesies dan $\left.H^{\prime}=0,94\right)$ dan parasitoid tertinggi ditemukan di Talang Buruk (2 species and $H^{\prime}=0,27$ ). Kelimpahan dan keanegaraman spesies predator dan parasitoid lebih tinggi pada musim kemarau dibandingkan musim hujan. Jadi, kelimpahan dan keanekaragaman spesies lebih tinggi di dataran rendah dibandingkan dataran tinggi di Sumatera Selatan, sedangkan musim juga mempengaruhi kelimpahan dan keanekaragaman spesies predator dan parastoid tersebut.

\section{SANWACANA}

Penelitian ini merupakan bagian dari Riset Dasar, Program Insentif Riset Dasar yang dibiayai oleh Program Insentif, Kementerian Negara Riset dan Teknologi, sesuai dengan Surat Perjanjian Pelaksanaan Program Insentif Tahun Anggaran 2010, Kontrak Nomor: 106/RD-DF/D.PSIPTN/Insentif/PPK/I/2010, tanggal 15 Januari 2010 yang diketuai oleh Siti Herlinda.

\section{DAFTAR PUSTAKA}

Amir M. 2002. Kumbang Lembing Pemangsa Coccinelldae (Coccinellinae) di Indonesia. Cetakan Pertama. Puslit Biologi-LIPI. Bogor.

Bugg RL, Colfer RG, Chaney WE, Smith HA \& Cannon J. 2008. Flower flies (Syrphidae) and other biological control agents for aphids in vegetable crops. ANR Publication 8285: 1-25.

Brewer MJ \& Elliot NC. 2004. Biological control of cereal aphids in North America and mediating effects of host plant and habitat manipulations. Annu. Rev. Entomol 49: 219-42.

De-Almeida RP. 2001. Effect of the population levels of Aphis gossypii on cotton agronomic traits and fibre quality. Proc. Exper. \& appl. Entomol. 12: $97-100$.

Fernandes? FL, Bacci L \& Fernandes MS. 2010. Impact and selectivity of insecticides to predators and parasitoids. EntomoBrasilis 3(1): 01-10.

Frechette B, Larouche F \& Lucas E. 2009. Leucopis annulipes larvae (Diptera: Chamaemyiidae) use a furtive predation strategy within aphid colonies. Eur. J. Entomol. 105: 399-403.

Giovanni G, Bazzocchi \& Burgio G. 2000. Functional response of Lysiphlebus testaceipes (Cresson) (Hymenoptera Braconidae) againts Aphis gossypii Glover (Homoptera Aphididae) at two constant temperatures. Boll. Lst. Ent. G. Grandi. Bologna 54:13-21.

Godfrey K \& McGuire M. 2004. Overwintering of Aphelinus near paramali (Hymenoptera: Aphelinidae), an introduced parasite of the cotton 
aphid in the San Joaquin Valley, California. Florida Entomologist 87(1): 88-91.

Godfrey LD, Rosenheim JA \& Goodell PB. 2000. Catton aphid emerges as major pest in SJV catton. California Agriculture 54(6): 26-29.

He XZ, Teulon DAJ \& Wang Q. 2006. Oviposition strategy of Aphidius ervi (Hymenoptera: Aphidiidae) in response to host density. New Zealand Plant Protection 59: 190-194.

Herlinda S. 2005. Jenis dan kelimphan parasitoid Plutella xylostella L. (Lepidoptera: Plutellidae) di Sumatera Selatan. Agria 1(2):78-83.

Herlinda S. 2010. Spore density and viability of entomopathogenic fungal isolates from Indonesia, and its virulence against Aphis gossypii (Glover) (Homoptera: Aphididae). Tropical Life Sciences Research. 21(1):13-21.

Hochberg ME \& Ives AR. 2000. Parasitoid Population Biology. Princeton University Press Princeton and Oxford. New Jersey. United Kingdom.

Idris AB, Roff MN \& Fatimah SG. 2001. Effects of chili plant architecture on the population abundance of Aphis gossypii Glover, its coccinellid predator and relationship with virus disease incidence on chili (Capsicum annum). Pakistan J. Biological Science 4 (11): 13561360.

Irsan C. 2003. Predator, parasitoid dan hiperparasitoid yang berasosiasi dengan kutudaun (Homoptera: Aphididae) pada tanaman talas. Hayati 10(2): 8184.

Joshi PC \& Sharma PK. 2008. First records of coccinellid beetles (Coccinellidae) from the Haridwar, (Uttarakhand), India. The Natural History Journal of Chulalongkorn University 8 (2): 157-167.

Khan I, Din S, Khalil SK \& Rafi MA. 2006. Survey of predatory coccinellids (Coleoptera: Coccinellidae) in the Chitral, District, Pakistan. Journal of Insect Science 7(7): 1-6.
Kuznetsov VN \& Zakharov EV. 2001. Distribution of lady beetles (Coleoptera, Coccinellidae) in plant formation in the Russian far east. Spec. Publ. Japan Coleopt. Soc. Osaka 1: 167-174.

Ludwig JA \& Reynolds F. 1988. Statistical Ecology. Jhon Wiley \& Sons, New York.

Ma XM, Liu XX, Zhang XW, Zhao JZ, Cai XN, Ma YM \& Chen DM. 2006. Assessment of cotton aphids, Aphis gossypii, and their natural enemies on aphid-resistant and aphid-susceptible wheat varieties in a wheat-cotton relay intercropping system. Entomologia Experimentalis et Applicata 121: 235-241.

Mayadunnage S, Wijayagunasekara HNP, Hemachandra KS \& Nugaliyadde L. 2007. Predatory coccinellids (Coleoptera: Cocinellidae) of vegetable insect pests: a survey in mid country of Sri Langka. Tropical Agriculture Research 19: 69-77.

Miyazaki M. 2001. Important aphid vectors of fruit tree virus diseases in tropical Asia. Plant Protection 1: $1-4$.

Nauen R \& Elbert A. 2003. European monitoring of resistance to insecticides in Myzus persicae and Aphis gossypii (Hemiptera: Aphididae) with special reference to imidacloprid. Bulletin of Entomological Research 93: 47-54.

Outward R, Sorenson CE \& Bradley JR. 2008. Effects of vegetated field borders on arthropods in cotton fields in Eastern North Carolina. Journal of Insect Science: 8 (9):1-16.

Rakhshani E, Talebi AA, Stary P, Tomanovic, Kavallieratos NG \& Manzari,S. 2008. A review of Aphidius Nees (Hymenoptera: Braconidae: Aphidiinae) in Iran: host associations, distribution and taxonomic Notes. Zootaxa 1767: 37-54.

Schirmer S, Sengonca C \& Blaeser P. 2008. Influence of abiotic factors on some biological and ecological characteristics of the aphid parasitoid Aphelinus asychis (Hymenoptera: Aphelinidae) parasitizing Aphis gossypii (Sternorrhyncha: Aphididae). Eur. J. Entomol. 105: 121-129. 
Sampaio MV, Bueno VHP \& De Conti BF. 2008. The Effect of the Quality and Size of Host Aphid Species on the Biological Characteristics of Aphidius colemani (Hymenoptera: Braconidae: Aphidiinae). Eur. J. Entomol. 105: 489-494.

Stary P, Sharkey M \& Hutacharern C. 2008. Aphid parasitoids sampled by Malaise traps in the National Parks of Thailand (Hymenoptera, Braconidae, Aphidiinae). Thai Journal of Agricultural Science 41(1-2): 37-43.

Stary P. 1988a. Aphidiidae. Pp. 171-184 In: Minks AK \& Harrewijn P, eds. Aphids: their biology, natural enemies and control. Vol 2B. Amsterdam: Elsevier.
Stary P. 1988b. Aphelinidae. Pp. 185-188 In: Minks AK \& Harrewijn P, eds. Aphids: their biology, natural enemies and control. Vol 2B. Amsterdam: Elsevier.

Wei JN, Bai BB, Yin TS, Wang Y, Yang Y, Zhao H, Kuang RP \& Xiang RJ. 2005. Development and use of parasitoids (Hymenoptera: Aphidiidae \& Aphelinidae) for biological control of aphids in China. Biocontrol Science and Technology 15(6): 533-551. 